\title{
Towards an understanding of cell-specific functions of signal- dependent transcription factors
}

\author{
Dawn X Zhang ${ }^{1,2}$ and Christopher K Glass ${ }^{1,3}$ \\ ${ }^{1}$ Department of Cellular and Molecular Medicine ${ }^{2}$ Biomedical Sciences Graduate Program ${ }^{3}$ Department of Medicine, \\ University of California, San Diego, 9500 Gilman Drive, La Jolla, California 92093, USA
}

Correspondence should be addressed to C K Glass Email ckg@ucsd.edu

\begin{abstract}
The ability to regulate gene expression in a cell-specific manner is a feature of many broadly expressed signal-dependent transcription factors (SDTFs), including nuclear hormone receptors and transcription factors that are activated by cell surface receptors for extracellular signals. As the most plastic cells of the hematopoietic system, macrophages are responsive to a wide spectrum of regulatory molecules and provide a robust model system for investigation of the basis for cell-specific transcriptional responses at a genome-wide level. Here, focusing on recent studies in macrophages, we review the evidence suggesting a model in which cell-specific actions of SDTFs are the consequence of priming functions of lineage determining transcription factors. We also discuss recent findings relating lineage-determining and SDTF activity to alterations in the epigenetic landscape as well as the production and function of enhancer RNAs. These findings have implications for the understanding of how natural genetic variation impacts cell-specific programs of gene expression and suggest new approaches for altering gene expression in vivo.
\end{abstract}
Key Words
- cell-specific
- lineage determining transcription factors
- signal dependent transcription factors
- genome-wide analyses

Journal of Molecular Endocrinology (2013) 51, T37-T50

\section{Introduction}

A central question in molecular endocrinology is how a single hormone-responsive transcription factor, reading the same DNA template, is capable of regulating different genes in different cell types. For example, activation of the glucocorticoid receptor by endogenous or synthetic glucocorticoids promotes a gluconeogenic program of gene expression in hepatocytes; mediates negative feedback control of adrenocorticotropic hormone secretion from the corticotrophs of the anterior pituitary; and suppresses pro-inflammatory responses of macrophages (Lazar 2011). In each case, the same glucocorticoid receptor controls the expression of a distinct set of genes that are crucial to the specific biological functions of the corresponding cell type. This ability to regulate gene expression in a cell-specific manner is shared by many broadly expressed signal-dependent transcription factors (SDTFs), including other nuclear hormone receptors and members of the diverse families of transcription factors that are activated by cell surface receptors for extracellular signals (e.g., STAT transcription factors, NF-кB family members, CREB, etc.). (For a complete listing of transcription factor names and abbreviations, see Table 1). The development of high-throughput sequencing methods to characterize transcription factor binding, histone modifications, and nascent RNA production at the genome-wide level has provided a powerful array of new tools for investigating the molecular basis for cell-specific transcriptional responses. These tools have been applied in a 
Table 1 Abbreviations and full names of transcription factors cited in this review

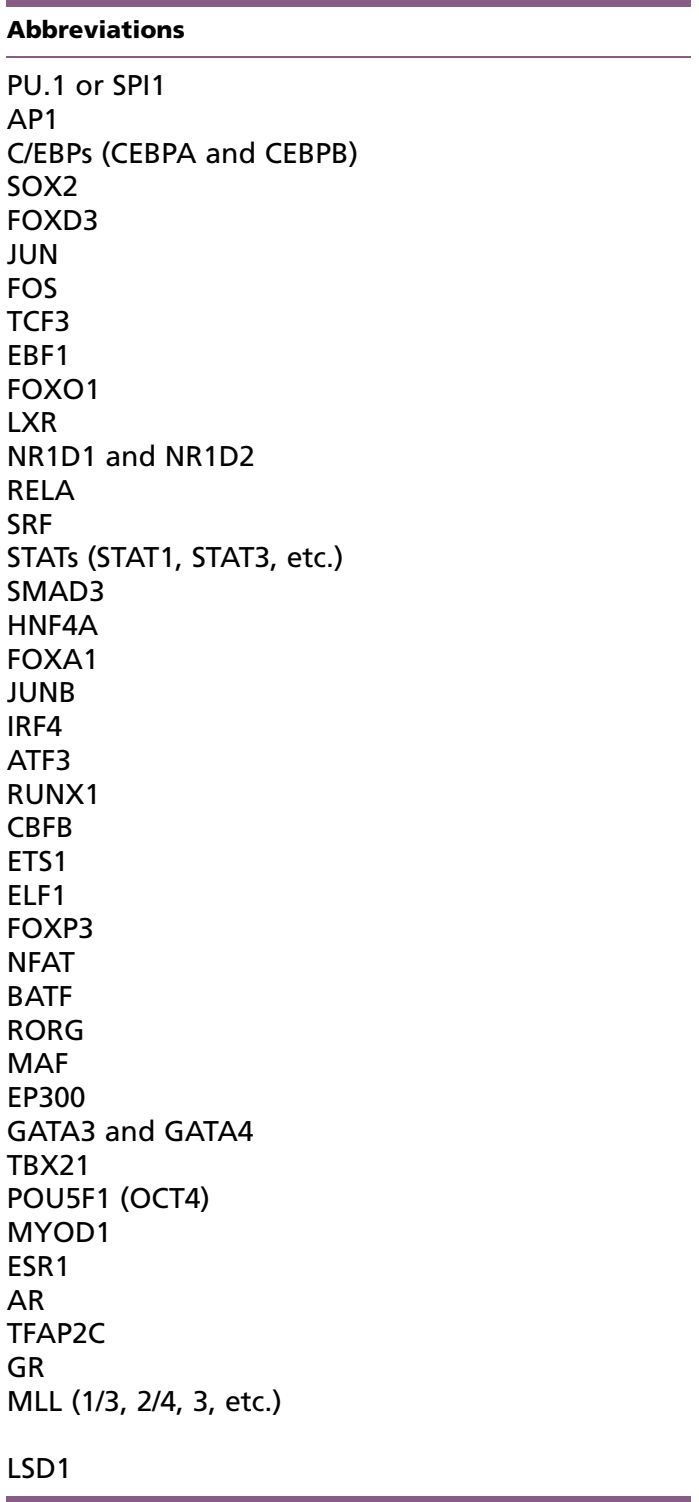

\section{Transcription factors}

Spleen focus-forming virus (SFFV) proviral integration oncogene SPI1

Activator protein 1 (heterodimeric protein complex)

CCAAT-enhancer-binding proteins $(\alpha$ and $\beta$ )

SRY (sex-determining region Y)-box 2

Forkhead box D3

Jun proto-oncogene

FBJ murine osteosarcoma viral oncogene homolog

Transcription factor 3

Early B-cell factor 1

Forkhead box 01

Liver $\mathrm{X}$ receptor

Nuclear receptor subfamily 1 , group $D$, members 1 and 2 (Rev-Erb $\alpha$ and $\beta$ )

$\mathrm{V}$-rel reticuloendotheliosis viral oncogene homolog A (avian)

Serum response factor

Signal transducer and activator of transcription (1, 3, etc.)

Mothers against decapentaplegic homolog 3 or SMAD family member 3

Hepatocyte nuclear factor $4, \alpha$

Forkhead box A1

Jun B proto-oncogene

Interferon regulatory factor 4

Activating transcription factor 3

Runt-related transcription factor

Core-binding factor, $\beta$ subunit

V-ets erythroblastosis virus E26 oncogene homolog 1 (avian)

E74-like factor 1 (ets domain transcription factor)

Forkhead box P3

Nuclear factor of activated T-cells

Basic leucine zipper transcription factor, ATF-like

RAR-related orphan receptor $C$

V-maf musculoaponeurotic fibrosarcoma oncogene homolog (avian)

E1A binding protein $\mathrm{p} 300$

GATA-binding protein 3 and 4

T-box 21

POU class 5 homeobox 1

Myogenic differentiation 1

Estrogen receptor 1

Androgen receptor

Transcription factor AP2 $\gamma$ (activating enhancer binding protein $2 \gamma$ )

Glucocorticoid receptor

Myeloid/lymphoid or mixed-lineage leukemia (trithorax homolog, Drosophila) $(1 / 3,2 / 4,3$, etc.)

Lysine (K)-specific demethylase $1 \mathrm{~A}$ number of biologically important model systems, including models for cellular differentiation (e.g., embryonic stem cell differentiation, adipogenesis, and hematopoiesis) and signal-dependent gene expression (e.g., macrophage activation and hormone-dependent breast and/or prostate cancers). In this review, we focus on recent insights into the molecular basis of cell-specific functions of broadly expressed SDTFs derived from genome-wide studies on macrophages.

Macrophages were discovered in 1884 by Ilya Mechnikov, a Russian bacteriologist who later shared the 1908 Nobel Prize in Physiology or Medicine with Paul
Ehrlich for their studies in innate immunity (Buryachkovskaya et al. 2013). Classically, macrophages differentiate from bone marrow-derived monocytes; however, recent studies have found that at least some tissue-resident macrophages such as microglia, Langerhans cells, and Kupffer cells are derived from hematopoietic stem cells during fetal development (Saijo \& Glass 2011, Wynn et al. 2013). As mediators of innate immunity and normal homeostatic processes, macrophages are essential to the body's ability to control inflammation. Consequently, these immune cells have been implicated in multiple disease processes such as diabetes, rheumatoid arthritis,

Published by Bioscientifica Ltd 
multiple sclerosis, and atherosclerosis (Drexler \& Foxwell 2010, Glass \& Saijo 2010, Olefsky \& Glass 2010). Primary macrophages are easily obtainable for in vitro studies (as bone marrow-derived macrophages, thioglycollate-elicited macrophages, circulating monocytes, splenic monocytes, etc.) from wild type and genetically modified animals and can also be differentiated from human blood monocytes. The ability to obtain large numbers of these cells makes them a robust model system for contemporary 'omics' technologies - proteomics (Hettinger et al. 2013, Meissner et al. 2013), lipidomics (Spann et al. 2012, Maurya et al. 2013), and genomics (Heinz et al. 2010, Kaikkonen et al. 2013, Lam et al. 2013, Ostuni et al. 2013) - for investigating signal-dependent mechanisms.

As the most plastic cells of the hematopoietic system, macrophages are responsive to many regulatory molecules, including growth factors, pro- and antiinflammatory cytokines, pathogen-associated molecular patterns (PAMPs), damage-associated molecular patterns (DAMPs), and nuclear receptor ligands (Smale 2010, Lawrence \& Natoli 2011, Murray \& Wynn 2011, Shi \& Pamer 2011, Sica \& Mantovani 2012, Van Dyken \& Locksley 2013, Wynn et al. 2013). Responses to PAMPs and DAMPs are mediated by pattern recognition receptors that include the family of toll-like receptors (TLRs; Medzhitov et al. 2011). TLR4 recognizes lipopolysaccharide (LPS), a component of the cell wall of Gram-negative bacteria. Upon binding LPS, TLR4 signal transduction activates a number of latent transcription factors, which include NF- $\kappa \mathrm{B}$ and interferon regulatory factors (Medzhitov et al. 1997, Poltorak et al. 1998a,b). These factors subsequently enter the nucleus and regulate the expression of inflammatory response genes, which play essential roles in innate immunity and contribute to the development of adaptive immunity (Medzhitov \& Horng 2009). This transcriptional response is among the most dramatic in biology with respect to both the number of genes regulated (thousands) and the magnitude of change in gene expression ( $>4$ orders of magnitude for the most highly regulated genes) (Escoubet-Lozach et al. 2011, Kaikkonen et al. 2013). This response is also subject to counter-regulation by anti-inflammatory signaling molecules that include ligands for nuclear hormone receptors, such as the glucocorticoid receptor, peroxisome proliferator-activated receptors (PPARs), and liver $\mathrm{X}$ receptors (LXRs) (Glass \& Saijo 2010). These properties of the macrophage make it a particularly rich cell type for the application of genome-wide approaches.

Recent studies of signal-dependent transcriptional responses in macrophages and $\mathrm{B}$ cells have suggested a

\section{Closed chromatin}

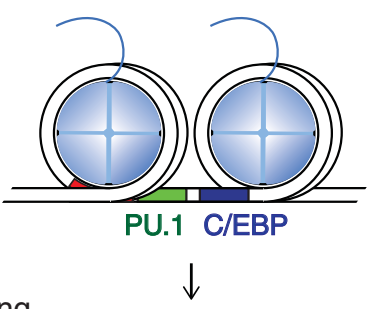

Collaborative binding

Nucleosome remodeling

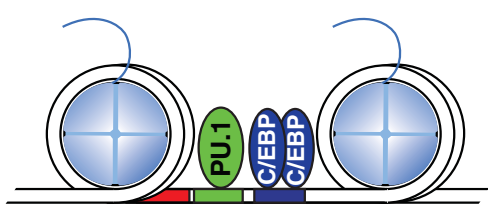

Basal enhancer transcription Low H3K4me1/2

Low H3Ac, H4Ac

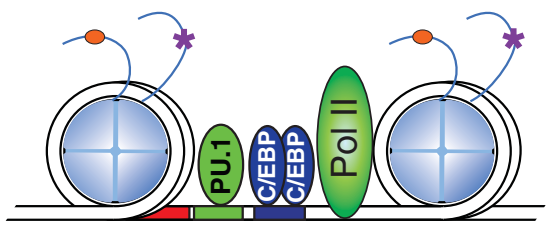

Signal-dependent transcription $\downarrow$ factor binding

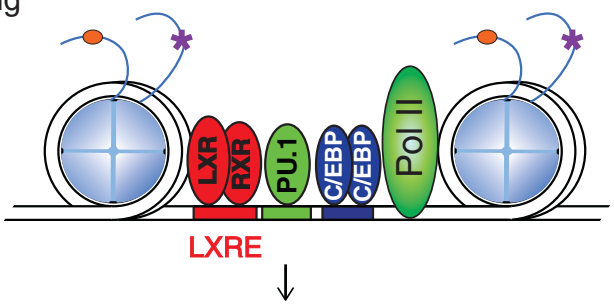

Activated enhancer transcription

Increased H3K4me1/2

Increased H3Ac, H4AC

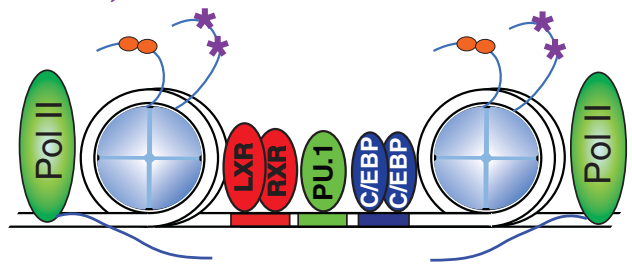

Figure 1

Hierarchical organization of transcription factor networks. In the poised or repressed state, closed chromatin at enhancer loci contains motifs for LDTFs. The collaborative binding of LDTFs such as PU. 1 and C/EBPs results in nucleosomal-remodeling and basal enhancer RNA transcription at sites containing low $\mathrm{H} 3 \mathrm{~K} 4 \mathrm{me} 1 / 2$ and low $\mathrm{H} 3 / \mathrm{H} 4$ acetylation. Next, in response to various stimuli, SDTFs, such as LXRs, co-bind with PU. 1 and C/EBPs to activate enhancer transcription. Finally, activated eRNA transcription precedes the active deposition of $\mathrm{H} 3 \mathrm{~K} 4 \mathrm{me} 1 / 2$ and $\mathrm{H} 3 / \mathrm{H} 4$ acetylation. LDTF, lineage-determining transcription factor; SDTF, signal-dependent transcription factor.

Published by Bioscientifica Ltd 
general model to explain many of the cell-specific functions of broadly expressed SDTFs (Heinz et al. 2010; Fig. 1). In this model, relatively simple combinations of lineage-determining transcription factors (LDTFs) are proposed to function collaboratively to select genomic enhancer-like regulatory regions in a cell-specific manner. The collaborative binding of these factors results in nucleosome remodeling to generate open regions of chromatin that provide access to SDTFs. Thus, SDTFs are directed to the vicinity of target genes in a cell-specific manner as a consequence of the priming functions of the lineage-determining factors for that particular cell type.

\section{Setting the stage: roles of lineage determining factors}

It has long been proposed that the functional output of transcription factors is determined by their competitive binding with nucleosomes. Until nucleosomes are displaced and chromatin regions are open, most transcription factors bind transiently to chromatin in a manner insufficient for efficient transcription (Lickwar et al. 2012). For example, during hematopoietic stem cell differentiation, nucleosome remodeling by the ATP-dependent, switch/sucrose nonfermentable (SWI/SNF) chromatin-remodeling complex allows for transcription factor binding at erythroid LDTF binding sites (Hu et al. 2011). Furthermore, studies utilizing novel high-throughput sequencing methods have been used to define open chromatin regions, which contain important transcriptional regulatory elements that delineate cell-specific identity (Song et al. 2011).

Recent studies of the ENCODE consortium estimate that the mammalian genome contains hundreds of thousands of enhancers (Bernstein et al. 2012), the majority of which are selected for activity in a cell-specific manner. This process of enhancer selection is proposed to result from collaborative interactions of LDTFs, also referred to as pioneer factors or master regulators. These factors are sequence-specific DNA-binding proteins with the ability to access their binding sites even when those sites are wrapped in nucleosomes. The factors also represent placeholders that can be replaced by other transcription factors at later stages during development (Zaret \& Carroll 2011). For example, in embryonic stem cells, developmental pioneer transcription factors, SOX2 and FOXD3, bind at tissue-specific elements, and are replaced by cell-specific transcription factors after differentiation (Liber et al. 2010). Currently, two prevailing theories exist to explain how pioneer transcription factors function in defining cell-specificity during development.
In the passive model, pioneer transcription factor occupancy decreases the number of binding events necessary for transcriptional activation (Zaret \& Carroll 2011). In contrast, the active model suggests that pioneer transcription factors function by recruiting chromatinremodeling complexes to activate transcription (Zaret \& Carroll 2011).

The roles of LDTFs in priming cell-specific regulatory sites have been well-characterized in cells of the hematopoietic lineage. The LDTF, spleen focus-forming virus (SFFV) proviral integration oncogene, SPI1, more commonly referred to as PU.1, provides a particularly instructive example of an LDTF that is required for specification of more than one hematopoietic cell type; genetic deletion of PU.1 results in loss of macrophages, neutrophils, and B cells (Scott et al. 1994, 1997). In myeloid lineage precursor cells, PU.1 instructs hematopoietic progenitors to upregulate myeloid-specific cell surface antigens and to downregulate other cell-specific markers and transcription factors (Nerlov \& Graf 1998). Recent studies have shown a dependence on cell cycle lengthening and subsequent PU.1 accumulation, which dictates myeloid differentiation from the common myeloid lymphoid progenitor (Kueh et al. 2013). In lymphoid progenitor cells, PU.1 is required for the expression of an alternative set of genes required for the progression to mature B cells (Lin et al. 2010). Thus, even a single LDTF can promote distinct programs of gene expression in different cell types.

PU.1 is a member of the E-twenty six (ETS) family of transcription factors, which bind to the canonical ETS-motif, 5'-GGAA-3'. Using genetic and genomic methods, PU.1 was recently shown to select macrophage or B cell-specific enhancers based on the co-occurrence of nearby binding sites for either macrophage or B-cell LDTFs, which are selectively expressed in one or the other cell type (Heinz et al. 2010). In macrophages, PU.1 binding occurred at enhancer-like regions exhibiting nearby binding sites for other essential myeloid LDTFs, CCAAT/enhancer binding protein $\alpha$ and $\beta$ (C/EBPs), and/or AP1 transcription factors, a heterodimeric protein composted of Jun proto-oncogene (JUN) and FBJ murine osteosarcoma viral oncogene homolog (FOS) (Heinz et al. 2010). In B cells, PU.1 binds at enhancer-like regions containing binding sites for other B cell LDTFs including TCF3, EBF1, and FOXO1 (Heinz et al. 2010, Lin et al. 2010). Notably, binding of PU.1 and alternative LDTFs was mutually dependent; genetic deletion of one factor resulted in loss of binding of the other at closely spaced sites (Heinz et al. 2010). Although generally within 100 bp

Published by Bioscientifica Ltd 
of each other, no strict spacing relationship was observed between PU.1 and collaborative transcription factor binding sites, suggesting a mechanism other than a ternary complex model for enhanced occupancy (Heinz et al. 2010). Gain-of-function studies indicated rapid nucleosome remodeling following collaborative binding of PU.1 to the regions destined to acquire enhancer-like features in myeloid cells based on subsequent H3K4 mono-methylation (Heinz et al. 2010). Furthermore, PU.1 is required for the maintenance of the macrophage epigenome and its expression in PU.1negative myeloid progenitors is sufficient to induce nucleosome remodeling and $\mathrm{H} 3 \mathrm{~K} 4$ mono-methylation at cell-specific sites (Heinz et al. 2010).

\section{SDTFs bind in a cell-specific manner}

Genome-wide studies to date of SDTFs indicate that while binding at promoters is enriched over that expected by chance, the majority of binding sites for these factors are located at inter- and intra-genic locations that exhibit the features of enhancers. Initially demonstrated for the estrogen receptor (Lupien et al. 2008), this pattern of genome-wide binding is also observed for other members of the nuclear receptor family, including the glucocorticoid receptor (Biddie et al. 2011), LXRs (Heinz et al. 2010), PPARG (Lefterova et al. 2008), androgen receptor (AR; Lupien et al. 2008, He et al. 2010, Wang et al. 2011), estrogen receptor-related receptors (Lupien et al. 2008, Hurtado et al. 2011, Li et al. 2013), and nuclear receptor subfamily 1 , group D, members 1 and 2 (NR1D1 and NR1D2), known colloquially as Rev-Erbs (Lam et al. 2013). Similarly, studies on transcription factors responsive to extracellular signals also primarily localize to distal enhancer-like elements, including the RELA component of NF-kB (Barish et al. 2010, Kaikkonen et al. 2013), serum response factor (SRF; Sullivan et al. 2011), FOXO1 (Fan et al. 2010), STAT1 (Vahedi et al. 2012), and SMAD3 (Mullen et al. 2011). Although identification of specific enhancer-promoter interactions remain challenging at a genome-wide level, the binding of SDTFs at distal locations is correlated with changes in expression of nearby genes (Kaikkonen et al. 2013, Lam et al. 2013).

In all of the cases in which the genome-wide locations of SDTFs have been examined in macrophages, a large fraction of the DNA-binding sites are observed to be in close proximity to the binding sites for one or more macrophage LDTFs (PU.1, C/EBPs, and/or AP1 factors) (Heinz et al. 2010). Because LDTFs select enhancers in a cell-specific manner, the colocalization of SDTFs implies a cell-specific binding pattern. Consistent with this, the genomic locations of PPARG and Rev-Erbs in macrophages are very different from their genomic locations in adipocytes (Lefterova et al. 2008) and hepatocytes (Cho et al. 2012) respectively.

An important question is the hierarchical relationship between LDTFs and SDTFs, as well as their respective roles in the selection of cell-specific enhancers. Studies of LDTFs and SDTFs in macrophages suggest the primary roles of LDTFs, with variable roles of SDTFs that depend on the specific factor analyzed. Genome-wide binding analyses of LXRs indicated that nearly all LXR-binding sites were in close proximity to the binding sites for macrophage LDTFs (PU.1, AP1, C/EBPs) (Heinz et al. 2010). Genetic deletion of LXRs had virtually no effect on the overall enhancer atlas in macrophages and did not result in a loss of nearby PU.1 binding (Heinz et al. 2010). In contrast, deletion of PU.1 resulted in loss of nearby LXR binding (Heinz et al. 2010). Thus, in this case, a clear hierarchy was observed in which the binding of LXRs was dependent on the initial selection of enhancers by LDTFs.

A different picture emerged from studies of the RELA subunit of NF- $\kappa \mathrm{B}$, which is strongly activated in macrophages by signaling through TLR4. Following activation and nuclear entry, $\sim 85 \%$ of RELA binding occurred at pre-existing enhancer-like regions of the genome that were occupied by macrophage LDTFs (Barish et al. 2010, Escoubet-Lozach et al. 2011, Kaikkonen et al. 2013). However, $\sim 15 \%$ of the binding sites for RELA occurred at the genomic regions that lacked features of enhancers, but acquired these features subsequent to RELA binding (Escoubet-Lozach et al. 2011, Kaikkonen et al. 2013). Intriguingly, these binding sites were highly enriched for nearby recognition motifs for the macrophage LDTFs AP1 and PU.1. Subsequent experiments demonstrated that RELA binding required PU.1, while PU.1 binding required nuclear entry of RELA (EscoubetLozach et al. 2011, Kaikkonen et al. 2013). Thus, in this case, RELA acted as both a signal-dependent and collaborating transcription factor to open up regions of chromatin and select new enhancers. The ability of RELA but not LXR to perform this function may relate to relatively higher nuclear concentrations and/or its ability to interact with nucleosome-remodeling factors.

Recent studies have utilized natural genetic variation as an in vivo mutagenesis screen to examine the collaborative binding model for LDTFs and the hierarchical relationship with NF-кB. Genome-wide transcription factor binding and gene expression analyses were used to characterize how genetic variations affect the binding of

Published by Bioscientifica Ltd 
LTDFs (PU.1 and CEBPA) and the associated transcriptional output in macrophages derived from two inbred rodent strains, C57BL/6J and BALB/c (Heinz et al. 2013). Single nucleotide variations and other noncoding genomic variants were shown to directly perturb LDTF as well as SDTF binding (Heinz et al. 2013). However, these studies have also demonstrated that a variant in a binding motif for an LDTF not only affected the binding of that factor but also the binding of nearby LDTFs, even though there were no alterations in the binding motifs for those factors. In the case of differential NF- $\kappa$ B binding in the two mouse strains, mutations in motifs of LDTFs were three times more likely to result in decreased RELA binding than mutations in the binding sites for RELA itself (Heinz et al. 2013). These findings provided genetic evidence that collaborative binding of LTDFs to variably spaced sequences was essential for enhancer selection and subsequent acquisition of histone modifications associated with enhancer activity (Heinz et al. 2013). These studies also provided genetic evidence for a hierarchical relationship between LDTFs and the majority of the binding sites for NF- $\kappa \mathrm{B}$.

From these studies, the authors also formulated a genetic definition of a functional binding matrix that could be used to predict whether a specific variant in an LDTF-binding motif would elicit a functional consequence. These results hint at the potential power of defining functionally important noncoding regulatory variants and suggest a strategy for prioritizing natural genetic variants that may play roles in human disease (Heinz et al. 2013).

A similar study detailed the binding profile of three tissue specific transcription factors (HNF4A, CEBPA, and FOXA1) in the livers of six inbred rodents (Stefflova et al. 2013). From these studies, the authors describe that although there are extensive transcription factor binding differences among relatively similar species, single nucleotide variation plays only a modest role in these differences (Stefflova et al. 2013). Regions that are bound by combinations of LDTFs are more evolutionarily stable; however, binding by a single LDTF can become destabilized through the deletion of one its LDTF co-binding partners (Stefflova et al. 2013).

\section{Lineage-determining factors in other cell types}

The roles of LDTFs in mediating cell-specific and signal dependent activation of transcription have been described in many cell types. Here, we provide examples derived from genome-wide studies in dendritic cells, T cells, and in model systems used to study transforming growth factor $\beta$ (TGF $\beta$ )-mediated and hormone-dependent gene expression (Table 2).

\section{Dendritic cells}

Dendritic cells and macrophages derive from a common myeloid lineage. In support of a LDTF/SDTF regulatory model, H3K4me3, H3K4me1, H3K27Ac, and a comprehensive panel of myeloid transcription factors were utilized to map the promoter and enhancer landscape in dendritic cells (Garber et al. 2012). Like in macrophages, the LDTFs in dendritic cells include PU.1 and CEBPB (Garber et al. 2012). In this model, a second tier of LDTFs (JUNB, IRF4, and ATF3) exists, termed 'primers', which co-bind with PU.1 and CEBPB at LPS-inducible genes pre-stimulation. Later, these factors become associated with specific and dynamic activation factors, mediating a signal-specific response to stimulation (Garber et al. 2012).

\section{T cells}

Three seminal papers have described the cell-specific enhancer landscape in $\mathrm{T}$ cells, focusing on variations amongst different subsets of $\mathrm{T}$ helper (Th) cells. In one study, the authors sought to define the subset-specific enhancer landscape in regulatory $\mathrm{T}$ (Treg) cells. LDTFs in the RUNX (Runt-related transcription factor) and ETS families, CBFB, ETS1, and ELF1, were shown to predominantly occupy quiescent $\mathrm{Th}$ cell enhancers (Samstein et al. 2012). Surprisingly, the majority of FOXP3 binds to both already established and Treg-polarized enhancers (Samstein et al. 2012). Only 2\% of FOXP3-binding sites appear to be Treg-specific and are highly enriched for an AP1 motif (Samstein et al. 2012). In some cases, FOXP3 was found to displace its paralog, FOXO1, or other cofactors that served as placeholders for FOXP3 binding (Samstein et al. 2012). Furthermore, during Treg polarization and TCR activation, the SDTF, FOXP3, is primarily recruited to previously established enhancers likely though AP1 and nuclear factor of activated T-cells (NFAT) facilitated chromatin remodeling (Samstein et al. 2012). A second study describing the transcriptional network for Th17 polarization has found two previously established LDTFs, BATF and IRF4, to exhibit similar binding patterns between quiescent Th cells and Th17 cells (Ciofani et al. 2012). In the presence of Th17-polarizing cytokines, BATF and IRF4 prime pre-established enhancers for SDTF (RORG, STAT3, and MAF) recruitment (Ciofani et al. 2012).

Published by Bioscientifica Ltd 
Table 2 Summary of studies demonstrating signal-dependent cell-specificity in transcription

\begin{tabular}{|c|c|c|c|c|c|}
\hline Cell type & $\begin{array}{l}\text { Lineage-determining } \\
\text { transcription factors }\end{array}$ & Stimulus & $\begin{array}{l}\text { Stimulus-activated } \\
\text { transcription factors }\end{array}$ & $\begin{array}{l}\text { Cell-specific } \\
\text { (LDTF-regulated) } \\
\text { gene expression }\end{array}$ & References \\
\hline Macrophages & PU.1, C/EBPs, AP1 & $\begin{array}{l}\text { LPS, GW3965 } \\
\text { (LXR agonist) }\end{array}$ & LXRs, RELA, BCL6 & $\begin{array}{l}\text { Csf1r, Cd14, Ccl3, } \\
\quad C c 14, C x c 12, A b c g 1\end{array}$ & $\begin{array}{l}\text { Barish et al. (2010) } \\
\text { and Heinz et al. } \\
(2010)\end{array}$ \\
\hline Dendritic cells & PU.1, CEBPB & LPS & JUNB, IRF4, ATF3 & $\begin{array}{r}\text { I/1a, Ifit1, Ifit2, Ifit3, } \\
\text { Tnf, Stat1, Nfkbiz }\end{array}$ & Garber et al. (2012) \\
\hline ES cells & POU5F1 & TGFB1 & SMAD3 & Sox 2 & Mullen et al. (2011) \\
\hline Pro-B cells & PU.1 & TGFB1 & SMAD3 & Vpreb2 & Mullen et al. (2011) \\
\hline Myotubes & MYOD1 & TGFB1 & SMAD3 & Adora 1 & Mullen et al. (2011) \\
\hline T cells & BATF and IRF4 & Th17 polarization & RORG, STAT3, MAF & I/17a, I/12rb1 & Ciofani et al. (2012) \\
\hline T cells & $?$ & $\begin{array}{l}\text { Th1 polarization } \\
\text { Th2 polarization }\end{array}$ & $\begin{array}{l}\text { STAT4, STAT1, TBX21 } \\
\text { STAT6, GATA3 }\end{array}$ & $?$ & Vahedi et al. (2012) \\
\hline T cells & CBFB, ETS1, ELF1 & Treg polarization & FOXP3 & Junb & $\begin{array}{l}\text { Samstein et al. } \\
\text { (2012) }\end{array}$ \\
\hline MCF7 cells & FOXA1, TFAP2C & Tamoxifen, $17 \beta$-estradiol & ESR1 & Ret, Xbp1, Tff1 & $\begin{array}{l}\text { Lupien et al. (2008), } \\
\text { Hurtado et al. } \\
\text { (2011), Tan et al. } \\
\text { (2011) and Li } \\
\text { et al. (2013) }\end{array}$ \\
\hline LNCaP cells & FOXA1 & $5 \alpha$-dihydrotestosterone & AR & Chka & $\begin{array}{l}\text { Lupien et al. (2008), } \\
\text { He et al. (2010) } \\
\text { and Wang et al. } \\
\text { (2011) }\end{array}$ \\
\hline $\begin{array}{l}\text { Murine mammary } \\
\text { epithelial cells }\end{array}$ & AP1 & Dexamethasone & $\begin{array}{l}\text { Glucocorticoid } \\
\text { receptor }\end{array}$ & KIrb1c & Biddie et al. (2011) \\
\hline U2OS & GATA4 & $17 \beta$-estradiol & ESR 1 & $\begin{array}{c}\text { Faslg, Wnt4, Foxc1, } \\
\text { Alpl, Runx2 }\end{array}$ & $\begin{array}{l}\text { Miranda-Carboni } \\
\text { et al. (2011) }\end{array}$ \\
\hline
\end{tabular}

Lastly, to define the active enhancer landscape after Th1 or Th2 polarization, a comprehensive analysis of EP300 binding was conducted in the two subsets (Vahedi et al. 2012). The two closely related cell subsets display common and distinct EP300 binding (Vahedi et al. 2012). Moreover, STAT6 and GATA3 or STAT4/STAT1 and TBX21 were found to activate Th2 or Th1 subset-specific enhancers, respectively, while suppressing those of alternative fates (Vahedi et al. 2012).

\section{Embryonic stem cells, pro-B cells, myotubes}

Genome-wide binding analyses were conducted for three unique cell types: embryonic stem cells, myotubes, and pro-B cells, each in the quiescent state and after TGF $\beta$ signaling (Mullen et al. 2011). The authors found that the LDTFs for these respective cell types, POU5F1, MYOD1, and PU.1, directed the TGF $\beta$-induced SDTF, SMAD3, to unique cell-specific enhancer sites (Mullen et al. 2011). Motif-finding at SMAD3 bound sites showed an enrichment for LDTF motifs specific to the cell type in question, highlighting the importance of LDTFs in directing the binding of SDTFs (Mullen et al. 2011).

\section{Breast, prostate, and osteoblasts}

FOXA1 is essential for the development and differentiation of several organs such as liver, kidney, pancreas, lung, prostate, and mammary gland (Friedman \& Kaestner 2006). In breast cancer epithelial (MCF7) cells and prostate cancer (LNCaP) cells, FOXA1 creates a cell-specific enhancer network, which regulates other activating factors such as ESR1 (Lupien et al. 2008, Hurtado et al. 2011) and AR (He et al. 2010, Wang et al. 2011) respectively. In estrogen-responsive breast cancer cells, tamoxifen-mediated ESR1 activity is dependent on LDTF FOXA1. In tamoxifen-resistant cells, ESR1 binding occurs independent of ligand but is still dependent on FOXA1 (Hurtado et al. 2011). Another transcription factor implicated in breast cancer oncogenesis, TFAP2C, binds to ESR1-binding sites in a ligand-independent manner, colocalizing with FOXA1 and priming enhancer sequences for ESR1 binding (Tan et al. 2011). Furthermore, treatment with estradiol results in a global increase in enhancer RNA (eRNA) transcription at enhancers in the vicinity of $17 \beta$-estradiol-regulated genes, which promote specific E2/ESR1/eRNA-induced enhancer-promoter looping

Published by Bioscientifica Ltd 
(Li et al. 2013). In addition, a recent study conducted in a murine mammary epithelial cell line has found AP1 to be an essential LDTF, mediating GR-chromatin interactions and GR-regulated transcription (Biddie et al. 2011).

In U2OS cells, an osteoblast-like cell line, ESR1 binding is preceded by the lineage determining factor, GATA4 (Miranda-Carboni et al. 2011). GATA4 is necessary for H3K4me2 deposition at ESR1-binding sites, suggesting that it is a LDTF for ESR1 recruitment in this cell type (Miranda-Carboni et al. 2011). Furthermore, these results illustrate the cell-specific nature of priming and activating transcription factors; future studies will help clarify the differences amongst diverse cell types.

\section{Histone modifications associated with active and poised regulatory elements}

LDTFs and SDTFs bind at both enhancer and promoter elements to regulate transcription. Enhancers and promoters are associated with distinct chromatin signatures - active promoters are marked by high levels of histone $\mathrm{H} 3$ lysine 4 tri-methylation (H3K4me3) relative to mono-methylation (H3K4me1), whereas enhancers are marked by high levels of H3K4me1 relative to H3K4me3 (Heintzman et al. 2007; Fig. 2). H3K4me2 occurs at both promoter and enhancer regions (Kaikkonen et al. 2013), which we define here by their distance from a transcription start site (around $<2 \mathrm{~kb}$ to indicate a promoter and $>2 \mathrm{~kb}$ to indicate an enhancer). Studies in yeast, Drosophila, and humans suggest that the SET domain-containing methyl-transferases are responsible for depositing the majority of H3K4me3 at promoters (Nagy et al. 2002, Wu et al. 2008, Ardehali et al. 2011, Hallson et al. 2012).

Mono-methylation at enhancers is dynamic and regulated in a cell-specific manner. Currently, methyltransferases regulating $\mathrm{H} 3 \mathrm{~K} 4 \mathrm{me} 1$ at mammalian enhancers include MLL1 (Jeong et al. 2011) and MLL1/3 (Kaikkonen et al. 2013). At enhancer loci, H3K4me1 functions as an active mark; its de-methylation in mouse embryonic stem cells by LSD1 results in enhancer silencing and cell differentiation. The process by which H3K4me1 is lost at enhancers is called enhancer 'decommissioning' and further illustrates the fine tuning mediated by cell-specific enhancers (Whyte et al. 2012). Not surprisingly, loss of LSD1 is associated with increased H3K4me1 and H3K4me2 at hematopoietic stem cell promoter and enhancer elements, as well as subsequent gene derepression, resulting in altered transcription and compromised differentiation (Kerenyi et al. 2013).

While the presence of H3K4me2 dictates active transcriptional regions, active enhancers are also marked

\section{Selected histone marks at promoters and enhancers}

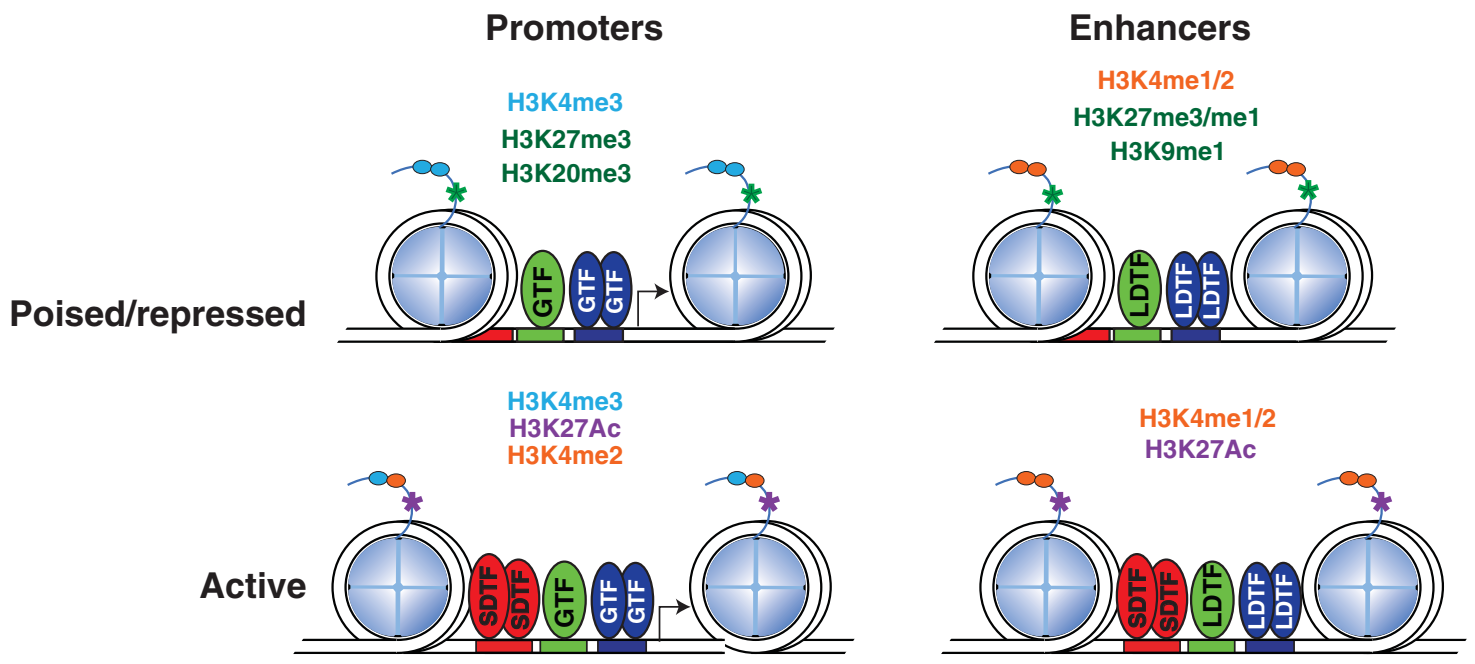

\section{Figure 2}

Histone marks at active and poised promoters and enhancers. Promoters are designated by high levels of $\mathrm{H} 3 \mathrm{~K} 4 \mathrm{me} 3$, while enhancers contain high levels of $\mathrm{H} 3 \mathrm{~K} 4 \mathrm{me} 1 / 2$. In the poised or repressed state, promoters contain histone methylation marks, $\mathrm{H} 3 \mathrm{~K} 27 \mathrm{me} 3$, and $\mathrm{H} 3 \mathrm{~K} 20 \mathrm{me} 3$, while enhancers (c) 2013 Society for Endocrinology Printed in Great Britain contain $\mathrm{H} 3 \mathrm{~K} 27 \mathrm{me} 3 / \mathrm{me} 1$ and $\mathrm{H} 3 \mathrm{~K} 9 \mathrm{me} 1$. Active promoters and enhancers are marked by $\mathrm{H} 3 \mathrm{~K} 4 \mathrm{me} 2$ and H3K27Ac. GTF, general transcription factor; LDTF, lineage-determining transcription factor; SDTF, signal-dependent transcription factor. 
by EP300 (or CBP) histone acetyl-transferase (Heintzman et al. 2007, Ghisletti et al. 2010; Fig. 2). ЕР300/СBP acetylates H3K27 (Tie et al. 2009, Pasini et al. 2010, Jin et al. 2011), a mark for active transcription, which distinguishes active enhancers from poised or disengaged enhancers (Heintzman et al. 2009, Creyghton et al. 2010, Rada-Iglesias et al. 2011, Zentner et al. 2011) in human and mouse embryonic stem cells (Creyghton et al. 2010, Rada-Iglesias et al. 2011, Zentner et al. 2011), as well as adult tissues (Heintzman et al. 2009, Creyghton et al. 2010, Zentner et al. 2011).

In contrast to active acetylation marks, the combination of H3K4me3 and H3K27me3 marks promoters that are 'poised' for transcription (Mikkelsen et al. 2007; Fig. 2). In mouse and human embryonic stem cells, poised enhancers are marked by H3K4me1, EP300, SMARCA4, and H3K27me3, and are bound by the Polycomb complex (Rada-Iglesias et al. 2011). Unable to drive gene expression, poised enhancers transition into active enhancers during differentiation through the acquisition of H3K27ac and the loss of H3K27me3, as well as the recruitment of tissuespecific transcription factors and RNA polymerase II (Rada-Iglesias et al. 2011). Furthermore, poised enhancers in hematopoietic stem cells contain H3K27me1 and H3K9me1 before their activation (Cui et al. 2009), whereas promoters in embryonic stem cells (Rada-Iglesias et al. 2011), hematopoietic stem cells (Cui et al. 2009), and adult tissues (De Santa et al. 2007), all contain H3K27me3 and may contain other repressive marks such as H3K20me3 (Stender et al. 2012; Fig. 2).

\section{Signal-dependent control of the epigenetic landscape}

Investigation of macrophage differentiation and activation has provided a powerful experimental system for linking the actions of LDTFs and SDTFs to specific histone modifications and subsequent transcriptional output. Macrophage gene expression is stimulus-specific, genespecific, cell-specific, and macrophage-subset specific. In early genome-wide studies to study the stimulus-specific nature of gene expression, microarrays were used to systematically examine the response of macrophages to various bacterial pathogens that act through TLRs, comparing the shared and differential transcriptional output (Nau et al. 2002). These studies were the first to document the very dramatic transcriptional responses of macrophages to these signals and revealed that these responses were finely tuned to specific pathogens.
Several lines of evidence indicate that the program of macrophage activation is subject to many types of negative regulation that act prior and/or subsequent to stimulus responses. BCL6 has been shown to corepress almost a third of the TLR4 cistrome, such that its loss results in hypersensitivity to pro-inflammatory derepression (Barish et al. 2010). The NCOR1/HDAC3 corepressor complex has been proposed to function as a transcriptional checkpoint for some TLR-responsive genes under basal conditions through recruitment to nonphosphorylated forms of AP1. The HDAC3 component of this complex contributes to the repressive functions of the NCOR1 complex by removing histone acetylation marks required for transcriptional activity (Ogawa et al. 2004; Fig. 3). Activation of inflammatory genes necessitates signal-dependent phosphorylation of c-Jun and removal of NCOR1 from AP1 target genes (Ogawa et al. 2004). Surprisingly, loss of HDAC3 in macrophages results in decreased activation of almost half of the inflammatory program (Chen et al. 2012). This phenomenon has been suggested to be the result of decreased Ifnb1 expression and the secondary STAT1-mediated transcriptional response, a pre-requisite for inflammatory induction (Chen et al. 2012). In addition to HDAC3, NCOR1 complexes in macrophages also contain the histone methyl-transferase SMYD5, which contributes to repression by catalyzing H4K20 tri-methylation, inhibiting the expression of TLR4 target genes (Stender et al. 2012). Signal-dependent de-methylation of H4K20me3 at promoters occurs through the recruitment of the histone de-methylase PHF2 by the RELA component of NF- $\kappa \mathrm{B}$ (Stender et al. 2012; Fig. 3).

After corepressor dismissal from inflammatory genes, transcriptional activation in response to TLR4 signaling occurs in two phases - primary response genes are immediately upregulated in response to stimuli whereas secondary response genes require expression of gene products from the initial wave of transcription, such as the type I interferons. CpG islands are usually found at the promoters of primary response genes and associate with nucleosome-destabilizing elements, allowing these genes to be transcribed at low levels in the basal state. This low level of transcription produces nonfunctional transcripts that are rapidly degraded until the recruitment of the positive transcription elongation factor (P-TEFb) complex, which phosphorylates RNA polymerase II and couples transcriptional initiation with elongation (Hargreaves et al. 2009, Ramirez-Carrozzi et al. 2009). In contrast, promoters with low CpG content are indicative of secondary response genes, which undergo stimulus-dependent

Published by Bioscientifica Ltd 


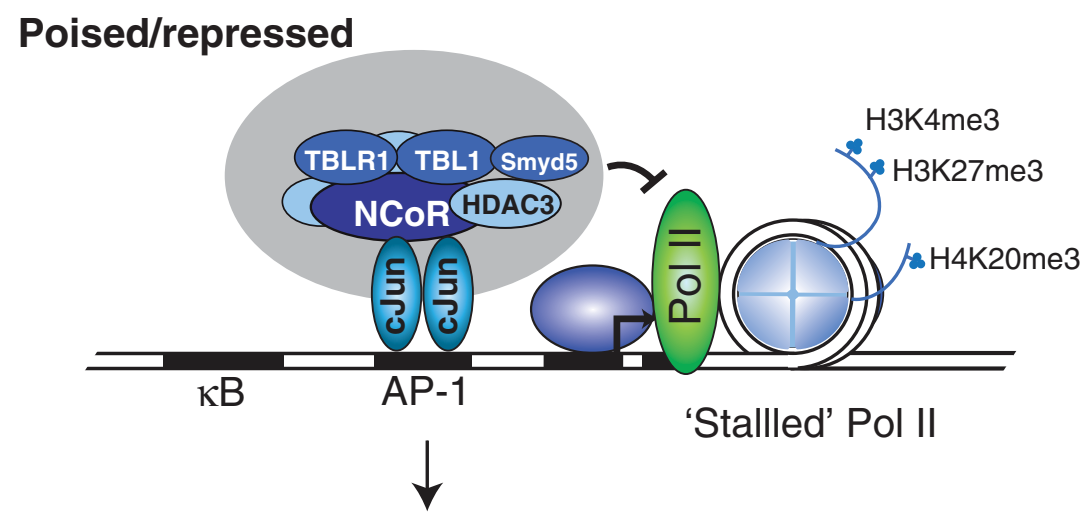

\section{Activation}

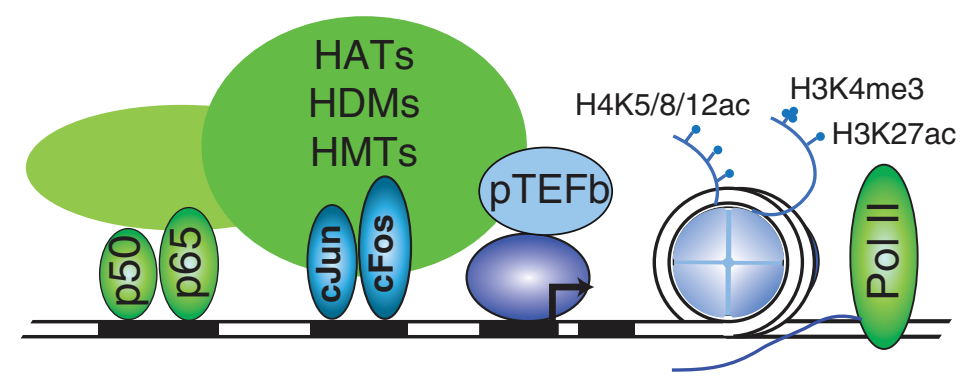

\section{Figure 3}

Mechanisms for regulating gene expression in macrophages: coregulator exchange from corepressor to coactivator. In the poised or repressed state, the NCOR1/HDAC3/SMYD5 complex inhibits active transcription through de-acetylation of histone $\mathrm{H} 3$ and $\mathrm{H} 4$, as well as tri-methylation of $\mathrm{H} 4 \mathrm{~K} 2 \mathrm{O}$.
After signal-dependent recruitment of activating transcription factors such as NF- $\mathrm{KB}$, the NCOR1 complex is exchanged for coactivator complexes that remove repressive marks and acetylate histones $\mathrm{H} 3$ and $\mathrm{H} 4$, recruiting the $\mathrm{P}$-TEFb complex to activate transcriptional elongation.
H3K4me3 and H3 acetylation, requiring selective nucleosome remodeling (Hargreaves et al. 2009, Ramirez-Carrozzi et al. 2009). Inflammatory genes in macrophages can be further classified into two categories on the basis of function and regulation - genes capable of being induced after stimulation of tolerant macrophages and those that will not be induced during restimulation. Genes capable of being restimulated exhibit more $\mathrm{H} 4$ acetylation and maintain H3K4me3 after restimulation (Foster et al. 2007). Like the genes in naïve macrophages, these genes are capable of recruiting the SMARCA4 and CHD4 chromatin-remodeling complexes to their promoters; however, they exhibit different transcriptional requirements than those in naïve macrophages (Foster et al. 2007).

Macrophage activation results in the sequential binding of lineage-determining and stimulus-activated transcription factors to cell-specific regions, enabling the novel deposition of cis-regulatory enhancer marks such as H3K4me1 and H3K27ac (Escoubet-Lozach et al. 2011,
Kaikkonen et al. 2013, Ostuni et al. 2013). In one study, the authors removed the stimuli post-treatment in a 'washout' experiment. Surprisingly, H3K4me1 did not revert to its latent state; instead, it persisted and conditioned a faster and stronger response upon restimulation, suggesting the existence of epigenetic memory in response to stimuli exposure (Ostuni et al. 2013).

Recent studies have reported the productive transcription of RNA polymerase II-associated noncoding RNA (De Santa et al. 2010) (ncRNA) from cis-regulatory enhancers located both intragenically (Kowalczyk et al. 2012) and intergenically in response to LPS stimulation (Kaikkonen et al. 2013). TLR4 signaling regulates macrophage gene expression through both a pre-existing enhancer landscape as well as the induction of $\sim 3000$ eRNAs from de novo enhancer regulatory regions (de novo eRNAs) (Kaikkonen et al. 2013; Fig. 1). In all, 2200 de novo eRNAs are induced greater than twofold in response to TLR4. Regions that show eRNA induction also gain H3K4me2 and are enriched for AP1, NF- $\kappa \mathrm{B}, \mathrm{C} / \mathrm{EBPs}$,

Published by Bioscientifica Ltd 
IRF/STAT, and PU.1 motifs (Kaikkonen et al. 2013). Surprisingly, the inhibition of RNA polymerase II elongation and eRNA synthesis at enhancers resulted in decreased H3K4me1 and H3K4me2 deposition without affecting H4K8ac (Kaikkonen et al. 2013). This result suggests that enhancer transcription precedes and may be essential for H3K4me1/2 deposition, at least for the set of enhancers that are established de novo following TLR4 activation. Systemic depletion of all known H3K4 methyl-transferases indicated that TLR4-induced H3K4 methylation was dependent upon the histone methyl-transferases, MLL1, MLL2/4, and MLL3 (Kaikkonen et al. 2013).

\section{Functional roles of eRNAs}

It has been proposed that transcription at enhancers maybe due to nonspecific interactions of RNA polymerase II with the genome, thus representing noise rather than biological function (Struhl 2007). Others have speculated that the functional effects of enhancer transcription are due to the transcription process and machinery or RNA polymerase II moving unobstructed in either direction upon binding DNA. In contrast, studies have shown that in vivo developmental enhancers have highly conserved noncoding elements (Pennacchio et al. 2006, Visel et al. 2008), positing that developmental enhancers may have retained their function throughout evolution.

eRNAs are believed to exert their function through two main mechanisms: in cis, the eRNAs may act on the same chromatin fiber or in trans, the eRNAs may function at distant sites in the genome. Recently, in macrophages, Rev-Erbs (NR1D1 and NR1D2, more commonly referred to as Rev-Erbs, see Table 1) have been described to repress key inflammatory genes through direct promotermediated mechanisms as well as in cis through eRNAs (Lam et al. 2013). Primarily, Rev-Erbs bind at distal elements, which are marked by PU.1 co-binding and H3K4me1 (Lam et al. 2013). The binding of Rev-Erbs at enhancer elements inhibits enhancer mediated transcription at two distal cis regulatory elements, subsequently decreasing transcription at the nearby protein-coding genes, Mmp9 and Cx3cr1 (Lam et al. 2013). Genetic studies depleting either Rev-Erbs from these loci or the eRNAs themselves resulted in the subsequent derepression of Mmp9 and Cx3cr1 mRNA (Lam et al. 2013). Similar studies on multiple cell types have found the transcription of ncRNAs, especially eRNAs, to be essential in promoting (Feng et al. 2006, Kim et al. 2010, Orom et al. 2010, Li et al. 2013, Melo et al. 2013) and inhibiting (Wang et al. 2008) gene expression. Further studies will help to elucidate the cell-specific mechanisms of enhancers in regulating diverse facets of transcription.

\section{Conclusions}

In concert, these studies suggest a general model to explain how genes with a broad distribution of expression can be regulated in a cell-specific manner and how broadly expressed SDTFs are capable of regulating discriminative responses in different cell types. Traditionally, the regulation of transcription is thought to occur primarily at the promoter. The above-described studies show that LDTFs collaboratively select and prime distal enhancer regulatory elements in a cell-specific manner, genome-wide. In a signal-dependent manner or during development, LDTFs may remodel and open chromatin at promoter and enhancer regions, broadly defining the regulatory potential of genes. For example, PU.1 binds to more than two-thirds of enhancer-like regions in macrophages, priming target genes for the subsequent recruitment of SDTFs to their vicinity, and their subsequent activation (Heinz et al. 2010). Thus, although transcription can occur at both promoters and enhancers - transcription at promoters is often ubiquitous amongst different cell-types while that at enhancers tends to be cell-specific.

Furthermore, genetic analyses have shown that mutations of SDTF motifs can only account for a small percentage of the variable gene expression that is the result of genetic variation (Kasowski et al. 2010, Heinz et al. 2013). Understanding how mutations in LDTF and SDTF motifs result in direct and indirect effects on enhancer selection and function is essential to defining relevant noncoding variants in the genome and their impact on human disease (Heinz et al. 2013). Comprehension of how key lineage determining transcription factors modulate signaldependent mechanisms in different cell types may also have cell-specific therapeutic applications. Many human disease states could benefit from cell-specific alterations in gene expression in a manner that would decrease toxicity and increase efficacy. New technologies such as antisense oligonucleotides and small interfering RNAs can be potentially used to modulate cell-specific eRNA transcripts that are associated with malfunctioning genes (Lam et al. 2013). In principle, this methodology would enable the cellspecific regulation of aberrant gene expression implicated in disease states such as cancer and chronic inflammatory diseases without adversely modulating normal physiological expression in unaffected cell types.

Published by Bioscientifica Ltd 


\section{Declaration of interest}

The authors declare that there is no conflict of interest that could be perceived as prejudicing the impartiality of the review.

\section{Funding}

D $X Z Z$ is supported by an American Heart Association Predoctoral Fellowship. These studies were also supported by NIH grants DK091183, DK074868, and CA17390 to C K G.

\section{Acknowledgements}

We would like to thank Karmel Allison for the critical reading of this manuscript and Lynn Bautista for her expertise in figure preparation.

\section{References}

Ardehali MB, Mei A, Zobeck KL, Caron M, Lis JT \& Kusch T 2011 Drosophila Set1 is the major histone H3 lysine 4 trimethyltransferase with role in transcription. EMBO Journal 30 2817-2828. (doi:10.1038/emboj. 2011.194)

Barish GD, Yu RT, Karunasiri M, Ocampo CB, Dixon J, Benner C, Dent AL, Tangirala RK \& Evans RM 2010 Bcl-6 and NF- $\kappa$ B cistromes mediate opposing regulation of the innate immune response. Genes and Development 24 2760-2765. (doi:10.1101/gad.1998010)

Bernstein BE, Birney E, Dunham I, Green ED, Gunter C \& Snyder M 2012 An integrated encyclopedia of DNA elements in the human genome. Nature 489 57-74. (doi:10.1038/nature11247)

Biddie SC, John S, Sabo PJ, Thurman RE, Johnson TA, Schiltz RL, Miranda TB, Sung MH, Trump S, Lightman SL et al. 2011 Transcription factor AP1 potentiates chromatin accessibility and glucocorticoid receptor binding. Molecular Cell 43 145-155. (doi:10.1016/j.molcel. 2011.06.016)

Buryachkovskaya L, Sumarokov A \& Lomakin N 2013 Historical overview of studies on inflammation in Russia. Inflammation Research 62 441-450. (doi:10.1007/s00011-013-0597-0)

Chen X, Barozzi I, Termanini A, Prosperini E, Recchiuti A, Dalli J, Mietton F, Matteoli G, Hiebert S \& Natoli G 2012 Requirement for the histone deacetylase Hdac3 for the inflammatory gene expression program in macrophages. PNAS 109 E2865-E2874. (doi:10.1073/pnas.1121131109)

Cho H, Zhao X, Hatori M, Yu RT, Barish GD, Lam MT, Chong LW, DiTacchio L, Atkins AR, Glass CK et al. 2012 Regulation of circadian behaviour and metabolism by REV-ERB- $\alpha$ and REV-ERB- $\beta$. Nature 485 123-127. (doi:10.1038/nature11048)

Ciofani M, Madar A, Galan C, Sellars M, Mace K, Pauli F, Agarwal A, Huang W, Parkurst CN, Muratet M et al. 2012 A validated regulatory network for Th17 cell specification. Cell 151 289-303. (doi:10.1016/j.cell.2012. 09.016)

Creyghton MP, Cheng AW, Welstead GG, Kooistra T, Carey BW, Steine EJ, Hanna J, Lodato MA, Frampton GM, Sharp PA et al. 2010 Histone H3K27ac separates active from poised enhancers and predicts developmental state. PNAS 107 21931-21936. (doi:10.1073/ pnas.1016071107)

Cui K, Zang C, Roh TY, Schones DE, Childs RW, Peng W \& Zhao K 2009 Chromatin signatures in multipotent human hematopoietic stem cells indicate the fate of bivalent genes during differentiation. Cell Stem Cell 4 80-93. (doi:10.1016/j.stem.2008.11.011)

De Santa F, Totaro MG, Prosperini E, Notarbartolo S, Testa G \& Natoli G 2007 The histone H3 lysine-27 demethylase Jmjd3 links inflammation to inhibition of polycomb-mediated gene silencing. Cell $\mathbf{1 3 0}$ 1083-1094. (doi:10.1016/j.cell.2007.08.019)
De Santa F, Barozzi I, Mietton F, Ghisletti S, Polletti S, Tusi BK, Muller H, Ragoussis J, Wei CL \& Natoli G 2010 A large fraction of extragenic RNA pol II transcription sites overlap enhancers. PLoS Biology 8 e1000384. (doi:10.1371/journal.pbio.1000384)

Drexler SK \& Foxwell BM 2010 The role of toll-like receptors in chronic inflammation. International Journal of Biochemistry \& Cell Biology 42 506-518. (doi:10.1016/j.biocel.2009.10.009)

Escoubet-Lozach L, Benner C, Kaikkonen MU, Lozach J, Heinz S, Spann NJ, Crotti A, Stender J, Ghisletti S, Reichart D et al. 2011 Mechanisms establishing TLR4-responsive activation states of inflammatory response genes. PLoS Genetics 7 e1002401. (doi:10.1371/journal.pgen.1002401)

Fan W, Morinaga H, Kim JJ, Bae E, Spann NJ, Heinz S, Glass CK \& Olefsky JM 2010 FoxO1 regulates Tlr4 inflammatory pathway signalling in macrophages. EMBO Journal 29 4223-4236. (doi:10.1038/emboj.2010.268)

Feng J, Bi C, Clark BS, Mady R, Shah P \& Kohtz JD 2006 The Evf-2 noncoding RNA is transcribed from the Dlx-5/6 ultraconserved region and functions as a Dlx-2 transcriptional coactivator. Genes and Development 20 1470-1484. (doi:10.1101/gad.1416106)

Foster SL, Hargreaves DC \& Medzhitov R 2007 Gene-specific control of inflammation by TLR-induced chromatin modifications. Nature $\mathbf{4 4 7}$ 972-978. (doi:10.1038/nature05836)

Friedman JR \& Kaestner KH 2006 The Foxa family of transcription factors in development and metabolism. Cellular and Molecular Life Sciences 63 2317-2328. (doi:10.1007/s00018-006-6095-6)

Garber M, Yosef N, Goren A, Raychowdhury R, Thielke A, Guttman M, Robinson J, Minie B, Chevrier N, Itzhaki Z et al. 2012 A highthroughput chromatin immunoprecipitation approach reveals principles of dynamic gene regulation in mammals. Molecular Cell $\mathbf{4 7}$ 810-822. (doi:10.1016/j.molcel.2012.07.030)

Ghisletti S, Barozzi I, Mietton F, Polletti S, De Santa F, Venturini E, Gregory L, Lonie L, Chew A, Wei CL et al. 2010 Identification and characterization of enhancers controlling the inflammatory gene expression program in macrophages. Immunity 32 317-328. (doi:10.1016/j.immuni.2010.02.008)

Glass CK \& Saijo K 2010 Nuclear receptor transrepression pathways that regulate inflammation in macrophages and T cells. Nature Reviews. Immunology 10 365-376. (doi:10.1038/nri2748)

Hallson G, Hollebakken RE, Li T, Syrzycka M, Kim I, Cotsworth S, Fitzpatrick KA, Sinclair DA \& Honda BM 2012 dSet1 is the main H3K4 di- and tri-methyltransferase throughout Drosophila development. Genetics 190 91-100. (doi:10.1534/genetics.111.135863)

Hargreaves DC, Horng T \& Medzhitov R 2009 Control of inducible gene expression by signal-dependent transcriptional elongation. Cell 138 129-145. (doi:10.1016/j.cell.2009.05.047)

He HH, Meyer CA, Shin H, Bailey ST, Wei G, Wang Q, Zhang Y, Xu K, Ni M, Lupien $\mathrm{M}$ et al. 2010 Nucleosome dynamics define transcriptional enhancers. Nature Genetics 42 343-347. (doi:10.1038/ng.545)

Heintzman ND, Stuart RK, Hon G, Fu Y, Ching CW, Hawkins RD, Barrera LO, Van Calcar S, Qu C, Ching KA et al. 2007 Distinct and predictive chromatin signatures of transcriptional promoters and enhancers in the human genome. Nature Genetics 39 311-318. (doi:10.1038/ng1966)

Heintzman ND, Hon GC, Hawkins RD, Kheradpour P, Stark A, Harp LF, Ye Z, Lee LK, Stuart RK, Ching CW et al. 2009 Histone modifications at human enhancers reflect global cell-type-specific gene expression. Nature 459 108-112. (doi:10.1038/nature07829)

Heinz S, Benner C, Spann N, Bertolino E, Lin YC, Laslo P, Cheng JX, Murre C, Singh H \& Glass CK 2010 Simple combinations of lineagedetermining transcription factors prime cis-regulatory elements required for macrophage and B cell identities. Molecular Cell $\mathbf{3 8}$ 576-589. (doi:10.1016/j.molcel.2010.05.004)

Heinz S, Romanoski CE, Benner C, Allison KA, Kaikkonen MU, Orozco LD $\&$ Glass CK 2013 Impact of natural genetic variation on enhancer selection and function. Nature [in press]. (doi:10.1038/nature12615)

Hettinger J, Richards DM, Hansson J, Barra MM, Joschko AC, Krijgsveld J \& Feuerer M 2013 Origin of monocytes and macrophages in a committed progenitor. Nature Immunology 14 821-830. (doi:10.1038/ni.2638) 
Hu G, Schones DE, Cui K, Ybarra R, Northrup D, Tang Q, Gattinoni L, Restifo NP, Huang S \& Zhao K 2011 Regulation of nucleosome landscape and transcription factor targeting at tissue-specific enhancers by BRG1. Genome Research 21 1650-1658. (doi:10.1101/gr.121145.111)

Hurtado A, Holmes KA, Ross-Innes CS, Schmidt D \& Carroll JS 2011 FOXA1 is a key determinant of estrogen receptor function and endocrine response. Nature Genetics 43 27-33. (doi:10.1038/ng.730)

Jeong KW, Kim K, Situ AJ, Ulmer TS, An W \& Stallcup MR 2011 Recognition of enhancer element-specific histone methylation by TIP60 in transcriptional activation. Nature Structural \& Molecular Biology 18 1358-1365. (doi:10.1038/nsmb.2153)

Jin Q, Yu LR, Wang L, Zhang Z, Kasper LH, LeeJE, Wang C, Brindle PK, Dent SY \& Ge K 2011 Distinct roles of GCN5/PCAF-mediated H3K9ac and CBP/p300-mediated H3K18/27ac in nuclear receptor transactivation. EMBO Journal 30 249-262. (doi:10.1038/emboj.2010.318)

Kaikkonen MU, Spann NJ, Heinz S, Romanoski CE, Allison KA, Stender JD, Chun HB, Tough DF, Prinjha RK, Benner C et al. 2013 Remodeling of the enhancer landscape during macrophage activation is coupled to enhancer transcription. Molecular Cell 51 310-325. (doi:10.1016/ j.molcel.2013.07.010)

Kasowski M, Grubert F, Heffelfinger C, Hariharan M, Asabere A, Waszak SM, Habegger L, Rozowsky J, Shi M, Urban AE et al. 2010 Variation in transcription factor binding among humans. Science 328 232-235. (doi:10.1126/science.1183621)

Kerenyi MA, Shao Z, Hsu YJ, Guo G, Luc S, O'Brien K, Fujiwara Y, Peng C, Nguyen M \& Orkin SH 2013 Histone demethylase Lsd1 represses hematopoietic stem and progenitor cell signatures during blood cell maturation. eLife 2 e00633. (doi:10.7554/eLife.00633)

Kim TK, Hemberg M, Gray JM, Costa AM, Bear DM, Wu J, Harmin DA, Laptewicz M, Barbara-Haley K, Kuersten S et al. 2010 Widespread transcription at neuronal activity-regulated enhancers. Nature $\mathbf{4 6 5}$ 182-187. (doi:10.1038/nature09033)

Kowalczyk MS, Hughes JR, Garrick D, Lynch MD, Sharpe JA, Sloane-Stanley JA, McGowan SJ, De Gobbi M, Hosseini M, Vernimmen D et al. 2012 Intragenic enhancers act as alternative promoters. Molecular Cell 45 447-458. (doi:10.1016/j.molcel.2011.12.021)

Kueh HY, Champhekhar A, Nutt SL, Elowitz MB \& Rothenberg EV 2013 Positive feedback between PU.1 and the cell cycle controls myeloid differentiation. Science 341 670-673. (doi:10.1126/science.1240831)

Lam MT, Cho H, Lesch HP, Gosselin D, Heinz S, Tanaka-Oishi Y, Benner C, Kaikkonen MU, Kim AS, Kosaka M et al. 2013 Rev-Erbs repress macrophage gene expression by inhibiting enhancer-directed transcription. Nature 498 511-515. (doi:10.1038/nature12209)

Lawrence T \& Natoli G 2011 Transcriptional regulation of macrophage polarization: enabling diversity with identity. Nature Reviews. Immunology 11 750-761. (doi:10.1038/nri3088)

Lazar MA 2011 Mechanism of action of hormones that act on nuclear receptors. In Williams Textbook of Endocrinology, 12th edn, pp 52-61. Eds S Melmed \& RH Williams. Philadelphia: Elsevier/Saunders.

Lefterova MI, Zhang Y, Steger DJ, Schupp M, Schug J, Cristancho A, Feng D, Zhuo D, Stoeckert CJ Jr, Liu XS et al. 2008 PPAR $\gamma$ and C/EBP factors orchestrate adipocyte biology via adjacent binding on a genome-wide scale. Genes and Development 22 2941-2952. (doi:10.1101/gad.1709008)

Li W, Notani D, Ma Q, Tanasa B, Nunez E, Chen AY, Merkurjev D, Zhang J, Ohgi K, Song X et al. 2013 Functional roles of enhancer RNAs for oestrogen-dependent transcriptional activation. Nature 498 516-520. (doi:10.1038/nature12210)

Liber D, Domaschenz R, Holmqvist PH, Mazzarella L, Georgiou A, Leleu M, Fisher AG, Labosky PA \& Dillon N 2010 Epigenetic priming of a pre-B cell-specific enhancer through binding of Sox 2 and Foxd3 at the ESC stage. Cell Stem Cell 7 114-126. (doi:10.1016/j.stem.2010.05.020)

Lickwar CR, Mueller F, Hanlon SE, McNally JG \& Lieb JD 2012 Genomewide protein-DNA binding dynamics suggest a molecular clutch for transcription factor function. Nature $\mathbf{4 8 4}$ 251-255. (doi:10.1038/ nature10985)
Lin YC, Jhunjhunwala S, Benner C, Heinz S, Welinder E, Mansson R, Sigvardsson M, Hagman J, Espinoza CA, Dutkowski J et al. 2010 A global network of transcription factors, involving E2A, EBF1 and Foxo1, that orchestrates B cell fate. Nature Immunology 11 635-643. (doi:10.1038/ ni.1891)

Lupien M, Eeckhoute J, Meyer CA, Wang Q, Zhang Y, Li W, Carroll JS, Liu XS \& Brown M 2008 FoxA1 translates epigenetic signatures into enhancer-driven lineage-specific transcription. Cell 132 958-970. (doi:10.1016/j.cell.2008.01.018)

Maurya MR, Gupta S, Li X, Fahy E, Dinasarapu AR, Sud M, Brown HA, Glass CK, Murphy RC, Russell DW et al. 2013 Analysis of inflammatory and lipid metabolic networks across RAW264.7 and thioglycolate-elicited macrophages. Journal of Lipid Research 54 2525-2542. (doi:10.1194/jlr.M040212)

Medzhitov R \& Horng T 2009 Transcriptional control of the inflammatory response. Nature Reviews. Immunology 9 692-703. (doi:10.1038/nri2634)

Medzhitov R, Preston-Hurlburt P \& Janeway CA Jr 1997 A human homologue of the Drosophila toll protein signals activation of adaptive immunity. Nature 388 394-397. (doi:10.1038/41131)

Medzhitov R, Shevach EM, Trinchieri G, Mellor AL, Munn DH, Gordon S, Libby P, Hansson GK, Shortman K, Dong C et al. 2011 Highlights of 10 years of immunology in Nature Reviews Immunology. Nature Reviews. Immunology 11 693-702. (doi:10.1038/nri3063)

Meissner F, Scheltema RA, Mollenkopf HJ \& Mann M 2013 Direct proteomic quantification of the secretome of activated immune cells. Science 340 475-478. (doi:10.1126/science.1232578)

Melo CA, Drost J, Wijchers PJ, van de Werken H, de Wit E, Oude Vrielink JA, Elkon R, Melo SA, Leveille N, Kalluri R et al. 2013 eRNAs are required for p53-dependent enhancer activity and gene transcription. Molecular Cell 49 524-535. (doi:10.1016/j.molcel.2012.11.021)

Mikkelsen TS, Ku M, Jaffe DB, Issac B, Lieberman E, Giannoukos G, Alvarez P, Brockman W, Kim TK, Koche RP et al. 2007 Genome-wide maps of chromatin state in pluripotent and lineage-committed cells. Nature $\mathbf{4 4 8}$ 553-560. (doi:10.1038/nature06008)

Miranda-Carboni GA, Guemes M, Bailey S, Anaya E, Corselli M, Peault B \& Krum SA 2011 GATA4 regulates estrogen receptor- $\alpha$-mediated osteoblast transcription. Molecular Endocrinology 25 1126-1136. (doi:10.1210/me.2010-0463)

Mullen AC, Orlando DA, Newman JJ, Loven J, Kumar RM, Bilodeau S, Reddy J, Guenther MG, DeKoter RP \& Young RA 2011 Master transcription factors determine cell-type-specific responses to TGF- $\beta$ signaling. Cell 147 565-576. (doi:10.1016/j.cell.2011.08.050)

Murray PJ \& Wynn TA 2011 Protective and pathogenic functions of macrophage subsets. Nature Reviews. Immunology 11 723-737. (doi:10.1038/nri3073)

Nagy PL, Griesenbeck J, Kornberg RD \& Cleary ML 2002 A trithorax-group complex purified from Saccharomyces cerevisiae is required for methylation of histone H3. PNAS 99 90-94. (doi:10.1073/pnas.221596698)

Nau GJ, Richmond JF, Schlesinger A, Jennings EG, Lander ES \& Young RA 2002 Human macrophage activation programs induced by bacterial pathogens. PNAS 99 1503-1508. (doi:10.1073/pnas.022649799)

Nerlov C \& Graf T 1998 PU.1 induces myeloid lineage commitment in multipotent hematopoietic progenitors. Genes and Development 12 2403-2412. (doi:10.1101/gad.12.15.2403)

Ogawa S, Lozach J, Jepsen K, Sawka-Verhelle D, Perissi V, Sasik R, Rose DW, Johnson RS, Rosenfeld MG \& Glass CK 2004 A nuclear receptor corepressor transcriptional checkpoint controlling activator protein 1-dependent gene networks required for macrophage activation. PNAS 101 14461-14466. (doi:10.1073/pnas.0405786101)

Olefsky JM \& Glass CK 2010 Macrophages, inflammation, and insulin resistance. Annual Review of Physiology 72 219-246. (doi:10.1146) annurev-physiol-021909-135846)

Orom UA, Derrien T, Beringer M, Gumireddy K, Gardini A, Bussotti G, Lai F, Zytnicki M, Notredame C, Huang Q et al. 2010 Long noncoding RNAs with enhancer-like function in human cells. Cell 143 46-58. (doi:10.1016/j.cell.2010.09.001)

Published by Bioscientifica Ltd 
Ostuni R, Piccolo V, Barozzi I, Polletti S, Termanini A, Bonifacio S, Curina A, Prosperini E, Ghisletti S \& Natoli G 2013 Latent enhancers activated by stimulation in differentiated cells. Cell 152 157-171. (doi:10.1016/ j.cell.2012.12.018)

Pasini D, Malatesta M, Jung HR, Walfridsson J, Willer A, Olsson L, Skotte J, Wutz A, Porse B, Jensen ON et al. 2010 Characterization of an antagonistic switch between histone $\mathrm{H} 3$ lysine 27 methylation and acetylation in the transcriptional regulation of Polycomb group target genes. Nucleic Acids Research 38 4958-4969. (doi:10.1093/nar/gkq244)

Pennacchio LA, Ahituv N, Moses AM, Prabhakar S, Nobrega MA, Shoukry M, Minovitsky S, Dubchak I, Holt A, Lewis KD et al. 2006 In vivo enhancer analysis of human conserved non-coding sequences. Nature $\mathbf{4 4 4}$ 499-502. (doi:10.1038/nature05295)

Poltorak A, He X, Smirnova I, Liu MY, Van Huffel C, Du X, Birdwell D, Alejos E, Silva M, Galanos C et al. 1998a Defective LPS signaling in $\mathrm{C} 3 \mathrm{H} / \mathrm{HeJ}$ and $\mathrm{C} 57 \mathrm{BL} / 10 \mathrm{ScCr}$ mice: mutations in Tlr4 gene. Science $\mathbf{2 8 2}$ 2085-2088. (doi:10.1126/science.282.5396.2085)

Poltorak A, Smirnova I, He X, Liu MY, Van Huffel C, McNally O, Birdwell D, Alejos E, Silva M, Du X et al. $1998 \mathrm{~b}$ Genetic and physical mapping of the Lps locus: identification of the toll-4 receptor as a candidate gene in the critical region. Blood Cells, Molecules \& Diseases 24 340-355. (doi:10.1006/bcmd.1998.0201)

Rada-Iglesias A, Bajpai R, Swigut T, Brugmann SA, Flynn RA \& Wysocka J 2011 A unique chromatin signature uncovers early developmental enhancers in humans. Nature 470 279-283. (doi:10.1038/nature09692)

Ramirez-Carrozzi VR, Braas D, Bhatt DM, Cheng CS, Hong C, Doty KR, Black JC, Hoffmann A, Carey M \& Smale ST 2009 A unifying model for the selective regulation of inducible transcription by CpG islands and nucleosome remodeling. Cell 138 114-128. (doi:10.1016/j.cell.2009. 04.020)

Saijo K \& Glass CK 2011 Microglial cell origin and phenotypes in health and disease. Nature Reviews. Immunology 11 775-787. (doi:10.1038/ nri3086)

Samstein RM, Arvey A, Josefowicz SZ, Peng X, Reynolds A, Sandstrom R, Neph S, Sabo P, Kim JM, Liao W et al. 2012 Foxp3 exploits a pre-existent enhancer landscape for regulatory T cell lineage specification. Cell $\mathbf{1 5 1}$ 153-166. (doi:10.1016/j.cell.2012.06.053)

Scott EW, Simon MC, Anastasi J \& Singh H 1994 Requirement of transcription factor PU.1 in the development of multiple hematopoietic lineages. Science 265 1573-1577. (doi:10.1126/science.8079170)

Scott EW, Fisher RC, Olson MC, Kehrli EW, Simon MC \& Singh H 1997 PU.1 functions in a cell-autonomous manner to control the differentiation of multipotential lymphoid-myeloid progenitors. Immunity 6 437-447. (doi:10.1016/S1074-7613(00)80287-3)

Shi C \& Pamer EG 2011 Monocyte recruitment during infection and inflammation. Nature Reviews. Immunology 11 762-774. (doi:10.1038/ nri3070)

Sica A \& Mantovani A 2012 Macrophage plasticity and polarization: in vivo veritas. Journal of Clinical Investigation 122 787-795. (doi:10.1172/ JCI59643)

Smale ST 2010 Selective transcription in response to an inflammatory stimulus. Cell 140 833-844. (doi:10.1016/j.cell.2010.01.037)

Song L, Zhang Z, Grasfeder LL, Boyle AP, Giresi PG, Lee BK, Sheffield NC, Graf S, Huss M, Keefe D et al. 2011 Open chromatin defined by DNaseI and FAIRE identifies regulatory elements that shape cell-type identity. Genome Research 21 1757-1767. (doi:10.1101/gr.121541.111)

Spann NJ, Garmire LX, McDonald JG, Myers DS, Milne SB, Shibata N, Reichart D, Fox JN, Shaked I, Heudobler D et al. 2012 Regulated accumulation of desmosterol integrates macrophage lipid metabolism and inflammatory responses. Cell 151 138-152. (doi:10.1016/j.cell. 2012.06.054)
Stefflova K, Thybert D, Wilson MD, Streeter I, Aleksic J, Karagianni P, Brazma A, Adams DJ, Talianidis I, Marioni JC et al. 2013 Cooperativity and rapid evolution of cobound transcription factors in closely related mammals. Cell 154 530-540. (doi:10.1016/j.cell.2013.07.007)

Stender JD, Pascual G, Liu W, Kaikkonen MU, Do K, Spann NJ, Boutros M, Perrimon N, Rosenfeld MG \& Glass CK 2012 Control of proinflammatory gene programs by regulated trimethylation and demethylation of histone H4K20. Molecular Cell 48 28-38. (doi:10.1016/j.molcel.2012. 07.020)

Struhl K 2007 Transcriptional noise and the fidelity of initiation by RNA polymerase II. Nature Structural \& Molecular Biology 14 103-105. (doi:10.1038/nsmb0207-103)

Sullivan AL, Benner C, Heinz S, Huang W, Xie L, Miano JM \& Glass CK 2011 Serum response factor utilizes distinct promoter- and enhancer-based mechanisms to regulate cytoskeletal gene expression in macrophages. Molecular and Cellular Biology 31 861-875. (doi:10.1128/MCB.00836-10)

Tan SK, Lin ZH, Chang CW, Varang V, Chng KR, Pan YF, Yong EL, Sung WK \& Cheung E 2011 AP- $2 \gamma$ regulates oestrogen receptor-mediated longrange chromatin interaction and gene transcription. EMBO Journal 30 2569-2581. (doi:10.1038/emboj.2011.151)

Tie F, Banerjee R, Stratton CA, Prasad-Sinha J, Stepanik V, Zlobin A, Diaz MO, Scacheri PC \& Harte PJ 2009 CBP-mediated acetylation of histone H3 lysine 27 antagonizes Drosophila Polycomb silencing. Development 136 3131-3141. (doi:10.1242/dev.037127)

Vahedi G, Takahashi H, Nakayamada S, Sun HW, Sartorelli V, Kanno Y \& O'Shea JJ 2012 STATs shape the active enhancer landscape of T cell populations. Cell 151 981-993. (doi:10.1016/j.cell.2012.09.044)

Van Dyken SJ \& Locksley RM 2013 Interleukin-4- and interleukin13-mediated alternatively activated macrophages: roles in homeostasis and disease. Annual Review of Immunology 31 317-343. (doi:10.1146/ annurev-immunol-032712-095906)

Visel A, Prabhakar S, Akiyama JA, Shoukry M, Lewis KD, Holt A, Plajzer-Frick I, Afzal V, Rubin EM \& Pennacchio LA 2008 Ultraconservation identifies a small subset of extremely constrained developmental enhancers. Nature Genetics 40 158-160. (doi:10.1038/ ng.2007.55)

Wang X, Arai S, Song X, Reichart D, Du K, Pascual G, Tempst P, Rosenfeld MG, Glass CK \& Kurokawa R 2008 Induced ncRNAs allosterically modify RNAbinding proteins in cis to inhibit transcription. Nature 454 126-130. (doi:10.1038/nature06992)

Wang D, Garcia-Bassets I, Benner C, Li W, Su X, Zhou Y, Qiu J, Liu W, Kaikkonen MU, Ohgi KA et al. 2011 Reprogramming transcription by distinct classes of enhancers functionally defined by eRNA. Nature $\mathbf{4 7 4}$ 390-394. (doi:10.1038/nature10006)

Whyte WA, Bilodeau S, Orlando DA, Hoke HA, Frampton GM, Foster CT, Cowley SM \& Young RA 2012 Enhancer decommissioning by LSD1 during embryonic stem cell differentiation. Nature 482 221-225. (doi:10.1038/nature10805)

Wu M, Wang PF, Lee JS, Martin-Brown S, Florens L, Washburn M \& Shilatifard A 2008 Molecular regulation of H3K4 trimethylation by Wdr82, a component of human Set1/COMPASS. Molecular and Cellular Biology 28 7337-7344. (doi:10.1128/MCB.00976-08)

Wynn TA, Chawla A \& Pollard JW 2013 Macrophage biology in development, homeostasis and disease. Nature 496 445-455. (doi:10.1038/nature12034)

Zaret KS \& Carroll JS 2011 Pioneer transcription factors: establishing competence for gene expression. Genes and Development 25 2227-2241. (doi:10.1101/gad.176826.111)

Zentner GE, Tesar PJ \& Scacheri PC 2011 Epigenetic signatures distinguish multiple classes of enhancers with distinct cellular functions. Genome Research 21 1273-1283. (doi:10.1101/gr.122382.111)

Received in final form 11 October 2013

Accepted 15 October 2013

Accepted Preprint published online 15 October 2013 http://jme.endocrinology-journals.org DOI: 10.1530/JME-13-0216
() 2013 Society for Endocrinology Printed in Great Britain
Published by Bioscientifica Ltd 